\title{
Quality Assurance in the Production of Teachers for Universal Basic Education (UBE)
}

\author{
Uchechukwu Linda Anaeto
}

Angelina Oyibo Asoegwu

Faculty of Education Imo State University,

Owerri-Nigeria

\section{Doi:10.5901/mjss.2013.v4n5p147}

\section{Abstract}

This paper highlights on the quality assurance of teacher production for universal Basic Education. It embraces knowledge empowerment, since the teacher is an integral part of the process of conceptualization, planning and execution in Universal Basic Education (UBE). This teacher production quality assurance will be measured on these areas:

1. The effectiveness of the teacher to use necessary resources available in schools to its optimal advantage in relation with the implementation of the Universal Basic Education programme.

2. The effectiveness of the teacher to use adequate textbooks on subjects available in the programme.

3. The effectiveness of the teacher in the use of information, communication and Technology in the programme.

4. The effectiveness of the teacher to use various instructional methods in teaching in the Universal Basic Education programme.

5. The effectiveness of the teacher to handle over-population and classroom arrangement in the programme.

Finally, the researcher summaries the paper and made some recommendations for away forward.

\section{Introduction}

Teachers are the key officers, indeed the line officers at any level of the educational system. As the line officers, they are directly responsible for the implementation of the curricular decisions that geared towards achieving the goals and objectives of education. Teachers are the hub of any educational system, as the wheel rotates around the hub, the educational system rotates round the teacher. Infact, no educational system can be better than its teacher. Since, teachers train tomorrow leaders and citizens to be hardworking in life. Therefore, there is the need for Nations to have a functional and well-articulated teachers. Haefele (1992) rightly observed that "No adequate training in school, can take place without competent teacher to handle the programe. However, for teachers to educate and encourage the spirit of enquiry and creativity in their students, obviously, the knowledge empowerment of the teacher quality assurance is important.

The teacher Education is one of the professional trainings for the purpose of producing highly trained, highly motivated, conscientious and efficient classroom teachers. It should provide the teachers with the intellectual and professional background full of the spirit of enquiry and creativity adequate for their assignment of impacting to Universal Basic Education pupils and students. This include primary one to Junior Secondary School, that required knowledge for individual development in the service of the national goals. More-over, the policy provides the following institutions for the training of Professional Teachers to quality assurance in Teacher Production to a required standard: FGN, (2004:40).

A. Colleges of Education 
B. Faculities of Education

C. Institutes of Education

D. National Teachers Institute

E. Schools of Education in the Polytechnics

F. National Institute for Nigerian Languages (NINLAN)

G. National Mathematical Centre (NMC)

All these institutes of Education are to train quality assurance Teacher production to take cognizance of change in Methodolgy and in the curriculum. For example regularly exposed to innovations in the profession through in-service training as to develop as a integral part of continuing teacher production. There should be transfer of service from state to state or even globally, nation to nation without loss of status. This will create professional growth through promotion opportunities. In addition, the teacher's Registration Council was setup to control and regulate the practice of the profession to quality assurance Teacher production.

\section{The Teacher Production Quality Assurance will be Measured on These Areas:}

1. The effectiveness of the teacher to use necessary resources available in schools to its optimal advantage in relation with the implementation of the Universal Basic Education Programme. According to Asoegwu, (2007:3) for any teacher to be quality assurance in production, there should be competent knowledge in the use of school library, basic health scheme, educational resources canters, modern science and technology laboratories. Also there should be mastery in the use of improvise and locally available materials to impact knowledge altitude and skills to pupils and students of Universal Basic Education Programme. With the effective and efficient use of the infrastructure to maintain acceptable standard in UBE programme which will in-turn produce the practical technical manpower needed for the nation's agricultural, industrial, commercial and economic development of the nation.

2. The effectiveness of using adequate textbooks on subjects available. If all teachers are professionally trained to quality assurance in Teacher production, they should be able to know adequate textbooks on subjects in the Universal Basic Education. These textbooks will include children's textbooks on the subjects available for the programme, with their workbooks and teacher's guide to enhance the intellectual and professional assignment adoptable to change situations positively. A teacher with quality assurance in production should discourage their pupils and students from memorizing facts and principles in textbooks for examination purposes rather they should acquire the knowledge, attitude and skills in the natural phenomena (learning by doing) Offorma, (1994:155) supported, that the teacher can supply information to the authors of the textbooks to ensure adequate, valid and reliable data are include, since he is part and parcel of the plan, in order to achieve the goals of the UBE.

3. The effectiveness of teacher in the use of information, communication and Technology (ICT) in teaching UBE programme. The efficient use of ICT in teaching universal basic Education pupils and students will benefit and develop in them ideas, values and skills necessary for the programme. Akuezuilo, (2006) observed that teachers can use ICT to prepare resources for instruction, access information and educational software through the internet, and communicate and exchange information with experts in specific fields with other schools and parents. FGN, (2004:17) had advised in recognition of the prominent role of information and communication Technology in advancing knowledge and skills necessary for effective functioning in the modern world. There is urgent need to integrate information and communication Technology (ICT) into education in Nigeria.

4. The effectiveness of using various instructional methods in teaching in the Universal Basic Education. Teacher Production with quality assurance can implement knowledge, attitude and skills 
in different instructional methods. The quality teacher will demonstrate his expertate in the various instructional methods like, Conventional, Guided-inquiry, Demonstration, Stimulation and Game, Group, Problem Solving, Discussion, Project, Questioning, Discovery, etc.

Ibe, (2006:145) stated that the need to use guided-inquiry and some other innovation teaching methods that are base on hands-methods in school to help learners relate activity experiences to home and to acquire science and technology skills. This can function efficiently with quality assurance in Teacher production. However, Adenike and Bisayo, (2003:94) had the opinion that any science graduate can handle integrated science and as a matter of fact, it was this Science graduates that were co-operated to teach the subject at its on set. That is, qualification has to do with quality assurance in Teacher Production.

5. The effectiveness of handling over-population and classroom arrangement in Universal Basic Education. This over population poses in the Universal Basic Education is a key factor, since the programme was made tuition free, universal and compulsory. FGN, (2004:16) had advised that for effective teaching and learning, the teacher pupil ratio shall be 1:35 that is one teacher to 35 pupils in a class. A quality assurance teacher should maintain this ratio for effective and efficient learning to take place. The quality

6. Teacher supposes to pay attention to every individual in the class. Therefore the Government should endeavour to train more quality teachers to handle overpopulation in the Universal Basic Education in Nigeria. In addition, quality assurance Teacher should be able to arrange his classroom to orderly. For instance the small pupils should seat in-front while the tall ones seat at the back to avoid obstruction. Also there should be sufficient ventilated and well-quipped classrooms. Obviously, should be enough infrastructure, laboratories, adequate textbooks, instructional materials. Libraries to accommodate the over population of pupils and students. These will lead to completion and high achievement rates in knowledge, attitudes and skills of the pupils.

\section{Conclusion}

For quality assurance in Teacher Production, they should be measured in knowledge acquisition, development of the intellectual capacities, well articulated and inculcation of the proper value orientation for the survival of the individual and society through teaching and research. Adenike and Bisayo, (2003:98) observed that qualification of the teacher also contribute significantly to the variation in the criterion variable. Since the teachers are looked upon for the support, guidance and protection of the children, there is need for quality and relevance of education being imparted to influence the lives of the nation's youth and invariably, the nation's future leaders. Hence, there is no how teaching and learning can be meaningful without the Teacher. The Universal Basic Education is meant to build a better tomorrow; therefore, teachers maintain discipline to ensure suitable atmosphere for work and activities in the classroom and beyond. Also quality teachers give the school its characters and tone, since they translate the schemes, aims and objectives of education into action in the classroom. Above all the quality assurance teacher should show exemplary character, truthful, fearless in teaching, inspire the pupils and perceive a sense of justice.

\section{Recommendations}

1. Federal, state and local government should train and retrain teachers through in-service education, conferences, Workshops and Seminars in order to produce more quality assurance in Teacher production for the loudable programme UBE. Since the rest of the education system is built upon it.

2. Federal Government should promote transfer of service from state to state or even globally, nation without loss of status. This will create professional growth through opportunities. 


\section{References}

Adenike and Bisayo, (2003). Integrated Science Inco-operated for Science Graduates.

Akuezuilo, (2006). The New 9-Year Basic Science and Technology Curriculum and The Challenges of its Implementation.

A Paper Presented at $6^{\text {th }}$ Biennial Conference of the World Council For Curriculum and Instruction Region 2, (African South of The Sahara) Nigeria Chapter.

Asoegwu, A.O. (2007). The Teacher Factor In The Implementation of the Universal Basic Education Programme. A Book Chapter In Okonkwo Owerri, Emurient Press.

Federal Republic of Nigeria (2004). National Policy on Education Lagos. $4^{\text {th }}$ Edition Federal Ministry of Information. Haefele, D.L. (1992). Evaluating Teacher: An Alternative Model. Journal of Personnel Evaluation in Education 5335-345. Ibe, (2006). Guided-Inquiry as Innovation in Teaching Methods.

Offorma, G.C. (1994) Curriculum Implementation and Instruction Owerri, UNI World Educational Publishers (Nig) Ltd. 